\title{
Effect of live Saccharomyces cerevisiae supplementation on growth, intake and rumen fermentation features in Tunisian Holstein Friesian fattening cattle
}

\section{O. Maamouri ${ }^{\mathrm{a}^{*}}$, M. Bouazizi ${ }^{\mathrm{b}}$ and A. Brahmi ${ }^{\mathrm{b}}$}

\begin{abstract}
${ }^{a}$ National Institute of Agronomic Research Tunisia, Universty of Carthage, ${ }^{b}$ High School of Agriculture of Kef, University of Jandouba, Tunisia

*Corresponding author: E-mail: omar_maamouri@yahoo.fr ; Tel: + (216) 97681104 and Fax: + (216) 71752897
\end{abstract}

Journal of Livestock Science (ISSN online 2277-6214) 10:22-28

Received on 17/1/2019; Accepted on 26/2/2019

doi. 10.33259/JLivestSci.2019.22-28

\begin{abstract}
The objective was to assess the effect of the addition of Saccharomyces cerevisiae yeast culture in the feeding of cattle's on in vitro digestibility and zootechnics performances. Sixteen Holstein cattle's were randomly divided into two equal groups ( 8 cattle's per group) during 147 days with 15 days of adaptation were used in this study according to age $(14.8 \pm 2.2$ months and 15.3 \pm 1.4 months respectively for control group (C) (group without yeast supply) and Yeast one (Y) (group receiving 28g live yeast /head/day)), initial body weight for the two groups $(413 \pm 21 \mathrm{~kg}$ (Pr. $>0.8))$ at the beginning of trial. Cattle's were either fed the same ration. Each cattle in the yeast group (Y) additionally received $28 \mathrm{~g} /$ head/day yeast of Saccharomyces cerevisiae in powder on the concentrate. Ration is composed of wheat straw $(5 \mathrm{~kg}$ DM/head/day) and concentrates (8kg $\mathrm{DM} / \mathrm{head} /$ day). The weights are made every 2 weeks with a livestock weighing scale. The refusal quantities of wheat straw are also weighed each control. It is noted that the entire quantity distributed concentrate is ingested. A significant $(\mathrm{P}<0.01)$ increase in the mean total daily gain $($ ADGT) during the trial was noted $(300) \mathrm{g} / \mathrm{head}$. And a significant $(\mathrm{P}<0.01)$ increase in the final weight gain $(\mathrm{FWG})$ of $(36.4) \mathrm{kg} / \mathrm{head}$ for the (Y) group compared to the $(\mathrm{C})$ group. Feed Intake does not differ with yeast intake. Voluntary feed intake increased for group $(\mathrm{Y})$ at $8^{\text {th }}$ week until the end of trial but without significatif difference. For food conversion, it was similar for $(\mathrm{Y})$ group and $(\mathrm{C})$ group with around $(2.61 \pm 0.004, \mathrm{P}>0.05)$, respectively.
\end{abstract}

Keywords: Fattening cattle's; Concentrate; Productivity; Nutrient digestion; Saccharomyces cerevisiae 


\section{Introduction}

In Tunisia, cattle's breeding is an important component of agricultural production and the national economy. As a result of population growth, the state has always invested in improving the beef sector to meet the ongoing need for red meat. The increase in the number of cattle was at the expense of the available food. This intensification of livestock production has led to excessive use of concentrated feeds and cereals in animal feeds, specifically in the fattening of young bulls. Nevertheless, to succeed fattening, certain conditions must be respected and a minimum of knowledge in breeding is necessary. In order to value their products and improve their incomes, these feeders increase the proportions of concentrated feeds in animal feed without taking into account the risks of metabolic diseases such as acidosis led by this misuse, leading to decreased performance. To prevent this risk, several studies have shown that the use of food additives seems to be an effective solution to limit the risk of latent acidosis in ruminants.

In particular, yeast Saccharomyces cereviciae has been widely studied (Chaucheyras-Durand et al., 2008; Desnoyers et al., 2006; Chaucheyras-Durand and Durand., 2010). They make it possible to maintain good animal health following digestive comfort and thus improve their zootechnic performance.

The objective of this study is to explore the effect of the addition of live Saccharomyces cerevisiae yeast in the feeding of cattle's on in vitro digestibility and zootechnic performance in intensify system.

\section{Materials and Methods}

Study area

Work was carried out between February and June 2017 in north eastern Tunisia, at the farm of a particular fattening breeder during 147 days. Analysis was carried out of Animal Nutrition laboratory of High School of Agriculture of Mateur, Tunisia.

Animals and experimental design

Sixteen Holstein cattle were split into two equal groups ((8) cattle per group) according to age (15 months), body weight $(413 \pm 21 \mathrm{~kg}$ ) fed the same ration (composed of wheat straw and concentrate). The ration consists of wheat straw ((5) $\mathrm{kg} \mathrm{DM} /$ head / day) and (8) $\mathrm{kg}$ DM concentrate for the control group (C) and for group (Y). Each bull of the yeast group (Y) received more than (C) group (28) g / head / day of yeast Saccharomyces cerevisiae powder on the concentrate.

Measurements

The weights were measured every two weeks with a cattle scale. We also calculated the average daily gain (ADG), the total daily gain (TADG), the final weight gain (FWG) and the feed conversion (FC). The refused quantities of wheat straw are also weighed each control with a balance. It should be noted that the entire amount of concentrate is ingested.

\section{Chemical analysis}

Chemical composition of various feed resources was determined in Animal Nutrition laboratory of High School of Agriculture of Mateur, Tunisia (Table 1). Nutritive values of experimental aliments were determined following the method described by Sauvant (1981). Samples of diets were dried in a forced-air oven at $105{ }^{\circ} \mathrm{C}$ for $24 \mathrm{~h}$ to determine DM. Dried samples were then ground through a 1-mm screen. Ground samples were used to determine ash content $\left(450^{\circ} \mathrm{C}\right.$ for $8 \mathrm{~h}$ ), crude fiber (CF) by the method of Weende (AOAC, 1984). Fat matter was determined by Randhall (AOAC, 1984). Crude protein (CP) was determined by Kjeldahl method (AOAC, 1984).

Statistical analysis

The results of the effects of diets on the measured parameters (weights, average daily gain (ADG), feed intake, food conversion (FC)) were subjected to analysis of variance with the GLM procedure of the statistical package SAS (2000) and compared by t-test diff. The statistical model was: $Y_{i j}=\mu+R_{i}+e_{i j}$

With: Yij: measured parameter; $\mu$ : overall mean; Ri: fixed effect of diet $(i=1,2)$; eij: residual error term.

\section{Results}

Chemical composition of foods

The chemical composition of foods is shown in Table 1. For wheat straw, it has a low crude protein (CP) content (4\%) and fodder unit (FU) $(0.4 \mathrm{FU} / \mathrm{kg} \mathrm{DM})$. The $\mathrm{CP}$ content could be considered deficient (Norton, 1994). For feed concentrate, CP and FU contents are $11.9 \%$ and $1.09 \mathrm{FU} / \mathrm{kg}$ DM respectively.

Growth weight (w) and average daily gain (adg)

The results showed that supplementation of $28 \mathrm{~g}$ yeast Saccharomyces cerevisiae per head per day in the food only increase significantly adg ( $2^{\text {th }}$ week) by $187.5 \mathrm{~g} / \mathrm{d} ;(\mathrm{P}<0.0006)$ and adg $\left(12^{\text {th }}\right.$ week $)$ by $98.4 \mathrm{~g} / \mathrm{d}$; $\mathrm{P}<0.04)$ respectively. There was a significant $(\mathrm{P}<0.01)$ increase of tadg (adg during all trial) by $300 \mathrm{~g} /$ head respectively for $\mathrm{Y}$ group and $\mathrm{C}$ one and a significant $(\mathrm{P}<0.02)$ increase of $(\mathrm{fdg})$ one (Table 2$)$. 
Table 1. Chemical composition and nutritive value of diets

\begin{tabular}{|l|l|l|}
\hline \multicolumn{1}{|c|}{ Diets } & Concentrate & Wheat bran \\
\hline DM & 89.61 & 89.51 \\
\hline TN (\%DM) & 1.90 & 0.64 \\
\hline CP (\%DM) & 11.9 & 4 \\
\hline CF (\%DM) & 6.3 & 29.3 \\
\hline Ash (\%DM) & 9.0 & 7 \\
\hline OM (\%DM) & 91.0 & 88.3 \\
\hline FM (\%DM) & 4.3 & - \\
\hline NEA (\%DM) & 68.5 & - \\
\hline PDIE (g / Kg DM) & 96 & 48 \\
\hline PDIN (g / Kg DM) & 80 & 22 \\
\hline FU / Kg DM & 1.06 & 0.4 \\
\hline
\end{tabular}

DM : dry matter; OM : organic matter; $\mathrm{CP}$ : crude protein; FM : fat matter; $\mathrm{CF}$ : crude fiber; FU : meat fodder unit : NEA : non extractif azote ; PDIE: digestible protein in the intestines of energy origin; PDIN: digestible proteins in the intestin of microbial when the ration is deficient in degradable nitrogen.

Table 2. Effect of Saccharomyces cerevisiae yeast feeding on growth (Weight (W)) and adg

\begin{tabular}{|c|c|c|c|c|c|}
\hline \multicolumn{2}{|c|}{ Item } & \multicolumn{2}{|c|}{ Group } & \multirow[t]{2}{*}{ MSE } & \multirow[t]{2}{*}{ Pr. $>\mathrm{F}$} \\
\hline & & Control & Yeast & & \\
\hline \multirow{10}{*}{$\begin{array}{l}\text { Weight } \\
(\mathrm{kg})\end{array}$} & 0 Week & $416.3 \pm 80.6$ & $409.4 \pm 50.8$ & 67.3 & 0.8 \\
\hline & $2^{\text {th }}$ Week & $442.0 \pm 79.9$ & $459.5 \pm 50.5$ & 66.9 & 0.6 \\
\hline & $4^{\text {th }}$ Week & $469.9 \pm 92.5$ & $492.3 \pm 48.3$ & 73.8 & 0.5 \\
\hline & $6^{\text {th }}$ Week & $486.5 \pm 92.2$ & $519.0 \pm 59.2$ & 77.5 & 0.4 \\
\hline & $8^{\text {th }}$ Week & $498.5 \pm 89.0$ & $535.3 \pm 65.1$ & 77.9 & 0.3 \\
\hline & $10^{\text {th }}$ Week & $510.9 \pm 91.0$ & $544.9 \pm 55.3$ & 76.6 & 0.4 \\
\hline & $12^{\text {th }}$ Week & $536.3 \pm 98.9$ & $585.0 \pm 54.5$ & 81.4 & 0.2 \\
\hline & $14^{\text {th }}$ Week & $557.6 \pm 102.3$ & $599.1 \pm 60.4$ & 85.5 & 0.3 \\
\hline & $16^{\text {th }}$ Week & $578.0 \pm 101.2$ & $610.1 \pm 56.8$ & 81.1 & 0.4 \\
\hline & $18^{\text {th }}$ Week & $603.9 \pm 98.9$ & $620.6 \pm 50.1$ & 80.1 & 0.6 \\
\hline \multirow{9}{*}{$\begin{array}{c}\text { Average } \\
\text { daily gain } \\
(\mathrm{g} / \mathrm{d})\end{array}$} & 0 Week & $198.1^{b} \pm 70.7$ & $385.6^{\mathrm{a}} \pm 97.9$ & 85.4 & 0.0006 \\
\hline & $2^{\text {th }}$ Week & $164.0 \pm 103.1$ & $192.6 \pm 69.1$ & 87.7 & 0.5 \\
\hline & $4^{\text {th }}$ Week & $79.2 \pm 46.0$ & $127.4 \pm 68.2$ & 58.1 & 0.1 \\
\hline & $6^{\text {th }}$ Week & $133.3 \pm 78.6$ & $180.6 \pm 124.8$ & 104.2 & 0.3 \\
\hline & $8^{\text {th }}$ Week & $103.1^{b} \pm 58.7$ & $210.7^{\mathrm{a}} \pm 102.7$ & 82.0 & 0.02 \\
\hline & $10^{\text {th }}$ Week & $169.2 \pm 94.4$ & $267.6 \pm 76.7$ & 86.7 & 0.04 \\
\hline & $12^{\text {th }}$ Week & $164.4 \pm 60.6$ & $174.7 \pm 62.8$ & 61.5 & 0.7 \\
\hline & $14^{\text {th }}$ Week & $203.8 \pm 75.0$ & $185.7 \pm 53.8$ & 66.0 & 0.6 \\
\hline & $16^{\text {th }}$ Week & $215.6 \pm 88.6$ & $196.4 \pm 83.3$ & 86.1 & 0.7 \\
\hline \multicolumn{2}{|c|}{$\begin{array}{l}\text { Total daily gain } \\
(0-18 \text { week })(\mathrm{g} / \mathrm{d})\end{array}$} & $1300^{\mathrm{b}} \pm 0.3$ & $1600^{\mathrm{a}} \pm 0.2$ & 25.9 & 0.01 \\
\hline \multicolumn{2}{|c|}{ Final weight gain $(\mathrm{Kg})$} & $187.6^{\mathrm{b}} \pm 33.1$ & $224^{\mathrm{a}} \pm 23.4$ & 0.2 & 0.02 \\
\hline
\end{tabular}

a. b Mean values with different letters in the same row are significantly different; MSE: mean standard error; $( \pm)$ : standard deviation;

Table 3. Effect of Saccharomyces cerevisiae on feed intake and food conversion (fc)

\begin{tabular}{|c|c|c|c|c|c|}
\hline \multicolumn{2}{|c|}{ Item } & \multicolumn{2}{|r|}{ Group } & \multirow[t]{2}{*}{ MSE } & \multirow[t]{2}{*}{ Pr. $>\mathrm{F}$} \\
\hline & & Control & Yeast & & \\
\hline \multirow{10}{*}{$\begin{array}{l}\text { Intake } \\
(\mathrm{g} \mathrm{DM} / \mathrm{d})\end{array}$} & 0 Week & $159.8 \pm 30.61$ & $157.2 \pm 19.30$ & 25.5 & 0.8 \\
\hline & $2^{\text {th }}$ Week & $169.6 \pm 30.37$ & $176.3 \pm 19.19$ & 25.30 & 0.6 \\
\hline & $4^{\text {th }}$ Week & $180.2 \pm 35.15$ & $189.6 \pm 18.35$ & 28.00 & 0.5 \\
\hline & $6^{\text {th }}$ Week & $186.5 \pm 35.02$ & $198.5 \pm 22.58$ & 29.4 & 0.4 \\
\hline & $8^{\text {th }}$ Week & $191.1 \pm 33.84$ & $205.0 \pm 24.74$ & 29.6 & 0.3 \\
\hline & $10^{\text {th }}$ Week & $195.8 \pm 34.56$ & $208.6 \pm 75.74$ & 58 & 0.4 \\
\hline & $12^{\text {th }}$ Week & $205.4 \pm 37.57$ & $223.9 \pm 80.90$ & 63 & 0.26 \\
\hline & $14^{\text {th }}$ Week & $213.5 \pm 38.89$ & $232.6 \pm 84.36$ & 65.7 & 0.27 \\
\hline & $16^{\text {th }}$ Week & $221.3 \pm 38.45$ & $239.6 \pm 86.48$ & 66 & 0.28 \\
\hline & $18^{\text {th }}$ Week & $231.1 \pm 37.59$ & $248.6 \pm 89.07$ & 68 & 0.28 \\
\hline \multirow{9}{*}{$\begin{array}{l}\text { Food } \\
\text { conversion }\end{array}$} & $2^{\text {th }}$ Week & $2.605 \pm 0.005$ & $2.607 \pm 0.003$ & 0.004 & NS \\
\hline & $4^{\text {th }}$ Week & $2.607 \pm 0.005$ & $2.597 \pm 0.033$ & 0.004 & 0.4 \\
\hline & $6^{\text {th }}$ Week & $2.608 \pm 0.005$ & $2.614 \pm 0.013$ & 0.004 & 0.33 \\
\hline & $8^{\text {th }}$ Week & $2.608 \pm 0.004$ & $2.610 \pm 0.003$ & 0.003 & 0.3 \\
\hline & $10^{\text {th }}$ Week & $2.609 \pm 0.004$ & $2.610 \pm 0.002$ & 0.003 & 0.4 \\
\hline & $12^{\text {th }}$ Week & $2.610 \pm 0.004$ & $2.610 \pm 0.002$ & 0.003 & 0.39 \\
\hline & $14^{\text {th }}$ Week & $2.611 \pm 0.004$ & $2.613 \pm 0.002$ & 0.003 & 0.23 \\
\hline & $16^{\text {th }}$ Week & $2.611 \pm 0.004$ & $2.613 \pm 0.002$ & 0.002 & 0.1 \\
\hline & $18^{\text {th }}$ Week & $2.612 \pm 0.003$ & $2.613 \pm 0.001$ & 0.002 & 0.23 \\
\hline
\end{tabular}

a. b Mean values with different letters in the same row are significantly different; MSE: mean standard error; $( \pm)$ : standard deviation. 


\section{Feed intake and feed conversion $(f c)$}

Voluntary intake increased for the $\mathrm{Y}$ group from the third control, but this increase wasn't mentioned a significant difference $(\mathrm{P}>0.05)$. For the feed conversion, it was similar for the $\mathrm{Y}$ group and the $\mathrm{C}$ group which was around $(2.6 \pm 0.003 ; \mathrm{P}<0.05)$ (Table 3$)$.

Parameters and rumen fermentation facies

This study showed (Table 4) that supplementation with yeast Saccharomyces cerevisiae didn't affect the facies' parameters fermentation (omd, vfa's concentration and ME) and also the ammoniacal nitrogen ( $>0.05$ ). In vitro gas production in 100 glass syringes ml undergoes a rapid evolution after incubation. After 24 hours of incubation the $\mathrm{C}$ diet registers the largest amount of gas $(62.5 \mathrm{ml} / 0.3 \mathrm{~g} \mathrm{DM})$ and is followed by the diet containing yeast Saccharomyces cerevisiae which gives a lower amount $(55.5 \mathrm{ml} / 0.3 \mathrm{~g})$ (Figure 1).

The kinetic parameters of the in vitro fermentation of different substrates, deduced from the exponential model of Orskov and Mc Donald (1979) are mentioned in the table 4.

Table 4. The parameters $a, b, c$ et $a+b$ of non linear model of gaz production and estimated parameters from gaz produced at 24 hours : comparaison of the two trial diets $(C)$ and (Y).

\begin{tabular}{|l|l|l|l|l|}
\hline \multirow{2}{*}{ Item } & \multicolumn{2}{c|}{ Group } & \multirow{2}{*}{ MSE } & \multirow{2}{*}{ Pr. $>$ F } \\
\cline { 2 - 3 } & \multicolumn{1}{|c|}{ Control } & \multicolumn{1}{c|}{ Yeast } & & \\
\hline $\mathrm{a}(\mathrm{ml})$ & $-3.1^{\mathrm{b}}( \pm 1.6)$ & $-2.7^{\mathrm{a}} \pm 2$ & $0.4 .10^{-4}$ & $<0.0001$ \\
\hline $\mathrm{b}(\mathrm{ml})$ & $109.6^{\mathrm{a}}( \pm 15)$ & $113.6^{\mathrm{b}} \pm 11$ & $0.36 .10^{-5}$ & $<0.0001$ \\
\hline $\mathrm{c}\left(\mathrm{h}^{-1}\right)$ & $0.02^{\mathrm{b}} \pm 0.0006$ & $0.03^{\mathrm{a}} \pm 0.0006$ & 0 & $<0.0001$ \\
\hline $\mathrm{a}+\mathrm{b}(\mathrm{ml})$ & $106.5^{\mathrm{a}} \pm 0.003$ & $110.9^{\mathrm{b}} \pm 0.001$ & - & $<0.0001$ \\
\hline Prod gaz $24 \mathrm{~h}(\mathrm{ml})$ & $42.7 \pm 8.8$ & $56.0 \pm 10.8$ & 15.3 & 0.4 \\
\hline Total Gaz $(\mathrm{ml})$ & $63.7 \pm 2.5$ & $64.3 \pm 0.6$ & 2.9 & 0.5 \\
\hline OMd $(\%)$ & $73.6 \pm 2.8$ & $76 \pm 1.4$ & 4.9 & 0.26 \\
\hline ME $(\mathrm{Kcal})$ & $1919 \pm 332$ & $2419 \pm 407$ & 576 & 0.4 \\
\hline VFA $(\mathrm{mmol} / \mathrm{syringe})$ & $1.27 \pm 0.07$ & $1.33 \pm 0.04$ & 0.004 & 0.26 \\
\hline $\mathrm{N}-\mathrm{NH}_{3}(\mathrm{mg} / \mathrm{ml})$ & $0.16 \pm 0.04$ & $0.20 \pm 0.02$ & 0.0009 & 0.15 \\
\hline
\end{tabular}

a. b Mean values with different letters in the same row are significantly different; MSE: mean standard error; ( \pm ): standard deviation; OMd: organic matter digestibilty ; ME: metabolic energy ; VFA: volatile fatty acids ; $\mathrm{N}_{-} \mathrm{NH}_{3}$ : ammoniacal nitrogen ; a: the amount of gas produced (ml) from the immediately soluble substrate; b: potential gas production: the amount of gas produced (ml) from the fraction of the insoluble but potentially degradable substrate ; $\mathrm{c}$ : the rate of gas production $(\% / \mathrm{h})$

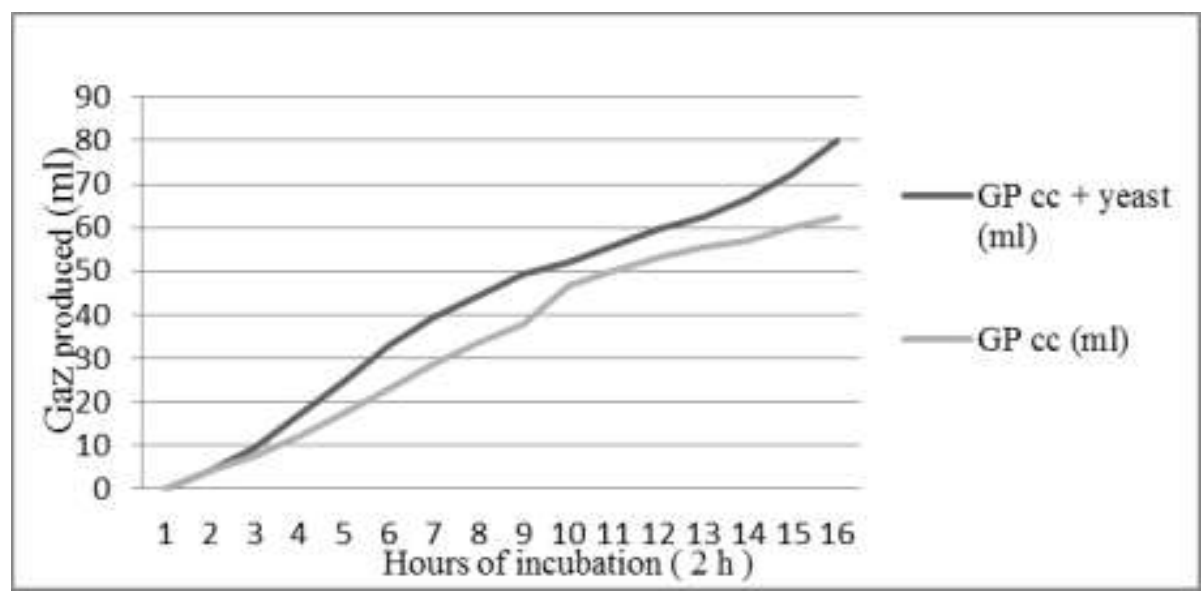

Figure 1. Kinetics of gas production by the two tested diets

The mixture (concentrated feed + yeast) is the most rapidly fermented by the microbiota ruminal $(0.03$ $\left.\left(\mathrm{h}^{-1}\right)\right)$ followed by concentrated feed) $\left(0.02\left(\mathrm{~h}^{-1}\right)\right)$. In vitro fermentation of two substrates is dependent on a lag phase, indicated by the negative value of the soluble fraction (a) $(-3.1 \mathrm{ml} / 0.3 \mathrm{~g}$ DM and $-2.7 \mathrm{ml} / 0.3 \mathrm{~g}$ DM respectively for $\mathrm{C}$ and $\mathrm{Y}$ diets respectively), which partly explains its low degradation.

This lag phase seems to be due to the time required for microorganisms to adhere and colonize dietary fiber. Regarding the other parameters, the values predicted mention that the digestibility of the organic matter of the concentrated feed alone is $73.6 \%$ and $76 \%$ for the mixture, which explains why the addition of yeast has no significant effect on this parameter $(\mathrm{P}=0.26>0.05)$. It's the same for $\mathrm{ME}$ released by the different substrates $(\mathrm{P}$ $=0.4>0.05)$. As well as despite VFA totals record, the respective values were 1.27 ( $\mathrm{mmol} / \mathrm{syringe})$ for the 
concentrated feed alone and 1.33 (mmol / syringe) for (concentrated feed + yeast), the statistical analysis shows no significant difference $(\mathrm{P}=0.26>0.05)$. As expected, the addition of the yeast culture increased the production of nitrogen ammoniacal (N-N3) for the two regimens (respectively $0.16 \pm 0.04$ and $0.20 \pm 0.02 \mathrm{mg} / \mathrm{ml}$ for (C) and (Y) groups). But without a significant difference $(\mathrm{P}=0.15>0.05)$.

\section{Discussion}

\section{Animal performance}

Throughout the experimental period, the distributed ration is energetic so that it can cover the corresponding requirements. It contains a high proportion of potentially acidogenic foods (about $60 \%$ of concentrated feed), the chemical composition and their dietary values are shown in Table 1 . The proportions in CP were respectively $11.5 \%$ for the concentrated feed, $11.9 \%$ for farm concentrate and $4 \%$ for straw. This ration can cause a state of ruminal acidosis (according to the feeder, it often records cases of acidosis marked by diarrhea and lameness). According to Sauvant and Giger-Reverdin (2016) this pathology is found almost systematically in intensive rearing when animals at high performance level receive rations rich in concentrated foods. Also, with proven results, Desnoyers (2008) has shown that the main causes of acidosis seem to be a poor adaptation of the rumen to the diet, too fast or too much ingesting and rapidly fermentable carbohydrates.

The evolution of the mean quantity of volontary ingested food during the trial period was 14.3 and 14.4 $\mathrm{kg} \mathrm{GM} /$ head/day respectively for the bulls of the $\mathrm{C}$ group and the experimental one $\mathrm{Y}$ during the first week of control. The intake sudden a slight increase after the $10^{\text {th }}$ week then it knows an improvement to reach its maximum towards the end of the test (20.7 vs. $22.7 \mathrm{Kg} \mathrm{GM} / \mathrm{head} / \mathrm{d}$ for the $\mathrm{C}$ group and Y one respectively) with a slight superiority for Y group.

Over the overall period, the two diets caused a different eating behaviour (Table 3). In fact the values of the total ingested green matter recorded $58.9 \pm 5.1$ and $56.1 \pm 8.4 \mathrm{~kg}$ for the $\mathrm{Y}$ and $\mathrm{C}$ groups respectively. It is clear that the incorporation of live yeast as a food additive has no significant effect on this measured zootechnical parameter $(\mathrm{P}=0.4>0.05)$. These results are consistent with what has been reported by Haimoud-Lekhal et al. (1999); Cano Lopez et al. (2010) and Desnoyers (2008) who found that yeast supplementation does not affect the amount ingested. While a study carried out by Moncoulon and Auclair (2001) showed that the incorporation of Saccharomyces cerevisiae yeast into the diet significantly reduced the amount of dry matter intake by $2.6 \%$.

During this work, the live weight of young cattle evolved from $373.3 \mathrm{~kg}$ to $564 \mathrm{~kg}$ for the $\mathrm{C}$ group and from $375 \mathrm{~kg}$ to $618 \mathrm{~kg}$ for the $\mathrm{Y}$ one at the end of the trial, with a remarkable superiority for the bulls of the $\mathrm{Y}$ group. According to Table 2, the bulls that did not receive a Saccharomyces cerevisiae yeast achieved a weight gain of $190.7 \mathrm{Kg}$ compared to $243 \mathrm{Kg}$ for those of the Y group. The statistical analysis reveals that these weight gains differ significantly $(\mathrm{P}=0.001<0.01)$ between the two groups with a significant difference of $52.3 \mathrm{Kg}$ is observed between the average values obtained. Regarding average daily gain (adg), the statistical analysis reveals that there are significant differences only for the $\operatorname{adg}\left(2^{\text {th }}\right.$ week $)(P=0.04<0.05)$ and the overall adg $(\mathrm{P}=$ $0.0008<0.01$ ) which has undergone a remarkable improvement. At $1970 \pm 0.03 \mathrm{~g} / \mathrm{d}$ for bulls that received a $\mathrm{Y}$ against $1560 \pm 0.03 \mathrm{~g}$ / day for the $\mathrm{C}$ group.

These results are consistent with those obtained by Majdoub-Mathlouthi et al. (2011) who showed that the addition of yeast to fattening bulls fed on poor forage resulted in an improvement in the adg of $39.6 \%$ with a significant increase $(\mathrm{P}<.0 .01)$ of the weight at the end of the trial. These results could probably be explained by an improvement in the parameters of ruminal fermentations. Indeed, Leloutre and Andrieus (2007) and also Desnoyers (2008) proved that, in general, the influence of yeasts is more important for diets rich in concentrate and for animals with a high level of ingestion. That is to say in the case of acidogenic diets distributed in farms conducted intensively. The yeast intake seems to be able to modify the physico-chemical parameters of the rumen in a way that is beneficial for the animal by allowing a greater synthesis of VFA and highly significant increases $(\mathrm{P}<0.01)$ of the concentration of acetate and propionate, while maintaining a relatively high $\mathrm{pH}$, decreasing the lactic acid concentration, improving the digestibility of the organic matter and subsequently inducing an increase in weight gain.

The results obtained (Table 3) showed that the diet supplemented by yeast caused on average a slight improvement in the index of food conversion (fc) to those obtained with the control diet $(7.6 \pm 2.5$ and $4.9 \pm 0.9 \mathrm{~kg}$ $\mathrm{GM} / \mathrm{kg}$ gain for $\mathrm{C}$ and $\mathrm{Y}$ groups respectively). The effect of this food additive on food conversion is significantly $(\mathrm{P}=0.02<0.05)$ on this experimental model suggesting that yeast probably improved rumen conditions (rumen comfort) and the efficacy of microbial flora in the rumen (Beauchemin et al., 2003).

From all the results obtained during this work, it appears that the capacity of this food additive to exert its effect in bulls lies in the improvement of food conversion, as has already been demonstrated in many cases (Cano Lopez et al., 2010, Majdoub-Mathlouthi et al., 2011). 


\section{Rumen fermentation parameters}

This trial allowed us to study the effects of yeast culture and their wall as a food additive on the fermental profile of the rumen which is characterized by different variables such as the digestibility of organic matter (OMD), the metabolizable energy (ME), volatils fatty acids (VFA) and ammoniacal nitrogen (N-NH3). These were determined after prediction by the in vitro gas production method (Menke and Steingass, 1988).

The gas production results for the different substrates as a function of time are shown in Figure 1. The production of in vitro gas in $100 \mathrm{ml}$ glass syringes undergoes rapid evolution after incubation. After 24 hours of incubation the control diet registers the largest amount of gas $(62.5 \mathrm{ml} / 0.3 \mathrm{~g} \mathrm{DM})$ and is followed by the diet supplemented by yeast which gives a smaller amount $(55.5 \mathrm{ml} / 0.3 \mathrm{~g})$.

The kinetic parameters of the in vitro fermentation of the different substrates, deduced from the exponential model of Orskov and Mc Donald (1979), are shown in Table 4. They reveal that the highest value of the volume of gas is recorded for the $\mathrm{Y}$ diet $(110.9 \mathrm{ml} / 0.3 \mathrm{~g} \mathrm{DM})$ against the $\mathrm{C}$ diet displays a lower value (106.5 ml/0.3 g DM).

The mixture (concentrated feed + yeast) is the most rapidly fermented by the ruminal microbiota $(0.03$ $\left.\left(\mathrm{h}^{-1}\right)\right)$ followed by the concentrated feed) $\left(0.02\left(\mathrm{~h}^{-1}\right)\right)$.

The in vitro fermentation of two substrates is dependent on a lag phase, indicated by the negative value of the soluble fraction (a) $(-3.1 \mathrm{ml} / 0.3 \mathrm{~g} \mathrm{DM}$ and $-2.7 \mathrm{ml} / 0.3 \mathrm{~g} \mathrm{DM}$ respectively for $\mathrm{C}$ and $\mathrm{Y}$ feeds), which partly explains its low degradation. This lag phase seems due to the time required for microorganisms to adhere and colonize dietary fiber. Concerning the other parameters, the predicted values mention that the digestibility of the organic matter of the concentrated feed alone is $73.6 \%$ and $76 \%$ for the mixture, which explains why the addition of the live yeast has no significant effect on this parameter $(P=0.26>0.05)$. It is the same for the metabolizable energie released by the different substrates $(P=0.4>0.05)$. As well as despite the fact that the total VFA record, the respective values were 1.27 (mmol/syringe) for the concentrated feed alone and 1.33 $(\mathrm{mmol} / \mathrm{syringe})$ for (the concentrated feed + yeast $)$, the statistical analysis shows no significant difference $(\mathrm{P}=$ $0.26>0.05)$.

As expected, the addition of the yeast culture increased the production of ammoniacal nitrogen $(\mathrm{N}$ $\mathrm{NH} 3)$ for the two regimes $(0.16 \pm 0.04$ and $0.20 \pm 0.02 \mathrm{mg} / \mathrm{ml}$ for the (C) and (Y) groups respectively).

In view of the results obtained in our test, the OMD, the concentration of the AGV and ME were not affected by the addition of the intake of the food additive, as was the ammonia nitrogen concentration of the rumen. Studies in adult animals have shown no effect of yeast supplementation on these fermental parameters of the rumen (Jouany 1994, Rey-mickael 2012). Conversely, a study by Marden (2007) showed an increase in ruminal VFA concentration during yeast supplementation. In addition, Desnoyers (2008) indicated that the influence of these types of additives on the digestibility of organic matter is positive for diets with less than $67 \%$ concentrate but negative for diets with more than $67 \%$ concentrate. Likewise, the positive effect of yeasts on certain parameters, such as $\mathrm{AGV}$, can also be simultaneously increased for diets rich in concentrate and rich in NDF.

The results are therefore extremely variable in the literature, which means that many factors, in particular the diet, can modify the influence of yeast on ruminal fermentations. The results found are in agreement with those of Cano Lopez et al. (2010) who found no significant differences between the two treatments at the level of the adg ( $>$ > 0.05), even if numerically it is higher in the animals that received the yeast. On the other hand, the trials carried out by El' Hassan et al. (1993) and Hancock et al. (1994) on young bulls reported a significant increase in adg when animals were fed an acidogenic diet and this could be the cause of the yeast effect which probably helps to limit fermentative disturbances in the rumen generally caused concentrated diets (Desnoyers, 2008).

\section{Conclusion}

The mode of action in the rumen of yeast culture appears to be associated with factors such as enzymes, peptides, and proteins associated with the fermentate on which the yeast cells were grown and extracted that affect microbial metabolism. Our results confirm the importance of yeast Saccharomyces cerevisiae supplementation in the diet of fattening cattle's to improve growth and final daily gain. And it appears crucial to explore the mechanisms of action of the Saccharomyces cerevisiae metabolic activities and intra-ruminal lipid and nitrogen metabolism of ruminants.

Acknowledgements Authors gratefully acknowledge the technical assistance of Mr Ben Othmane from $\mathrm{OEP}, \mathrm{Mr}$ Amrawi from High School of Agriculture of Mateur and Mr Sales Manager in Northwest Africa and Middle East of Arm and Hammer Animal Nutrition Church and Dwight Co., Inc; for their logistic help.

Disclosure statement No potential conflict of interest was reported by the authors. 


\section{References}

1) AOAC. Association of Official Analytical Chemists, 1984. Official Methods of Analysis. 14th ed. USA.

2) Beauchemin K A, Yang W Z, Morgavi D P, Ghorbani G R, Kautz W, Leedle J A Z, 2003. Effects of bacterial direct-fed microbials and yeast on site and extent of digestion, blood chemistry, and subclinical ruminal acidosis in feedlot cattle. Journal of Animal Science, volume 81, 1628-1640

3) Cano Lopez G, Villalba Mata D, Philippe F, 2010. Comparaison de l'effet de l'apport en levures Saccharomyces cerevisiae vivantes ou inactivées sur les performances de croissance de bovins en engraissement. Rencontre. Recherche. Ruminants, 17.

4) Chaucheyras-Durand F, Walker N, Bach A, 2008. Effects of active dry yeasts on the rumen microbial ecosystem: Past, present and future. Animal Feed Science and Technology, 145, (1), 5-26.

5) Chaucheyras-Durand F, Durand H, 2010. Probiotics in animal nutrition and health. Lallemand Animal Nutrition, Blagnac, France. Beneficals Microbes. 1(1) : 3-9.

6) Desnoyers M, 2008. Intérêt de l'apport de levures sur la Susceptibilité à l'acidose et le Comportement alimentaire de ruminant (Application à la chèvre laitière). Thèse de Doctorat l'Institut des Sciences et Industries du Vivant et de l'Environnement (AgroParisTech).

7) Desnoyers M, Duvaux-ponter C, Bertin G, Roussel S, Tessier J , Piquerel P, Giger-Reverdin S, 2006. Effets de l'apport de levures (Saccharomyces cerevisiae CBS493.94) sur le comportement et la réactivité émotionnelle de chèvres laitières en acidose subclinique. Rencontre. Recherche. Ruminants. 13, 137.

8) El Hassan S M, Newbold C J, Wallace R J, 1993. The effect of yeast in the rumen and the requirement for viable yeast cells. Animal. Production. 54: 504 (Abstract).

9) Haimoud-Lekhal D A, Lescoat P, Bayourthe C, Moncoulon R, 1999. Effets de Saccharomyces cerevisae et Aspergillus oryzae sur les performances zootechniques chez la vache laitière. Étude bibliographique in 6èmes Rencontres autour des Recherches sur les Ruminants, Paris, France 157.

10) Jouany J P, 1994 (http://www.bicarz.com/fr/binaries/Etude-Jouany-178384.pdf).Mieux comprendre le rumen, un fermenteur multitâche très efficace. Rapport Scientifique. Pages 4-5.

11) Leloutre L, Andrieu S, 2007. Etude comparée de l'effet de l'addition d'une levure vivante (Yea-Sacc1026) ou de levures mortes sur les paramètres de fermentation du rumen de vaches fistulées. Rencontre. Recherche. Ruminants, 2007, 14

12) Majdoub-Mathlouthi L, Chammaoui A, Kraiem K, 2011. Effet de la levure Saccharomyces cerevisiae sur les performances des taurillons à l'engraissemnt alimentés à base de fourrages pauvres. Livestock Research for Rural Development. 23 (11).

13) Marden Jean-Philippe, 2007. Contribution à l'étude du mode d'action de la levure Saccharomyces cerevisiae Sc47 chez le ruminant : Approche thermodynamique chez la vache laitière. Thèse doctorat. SEVAB. 232 pages.

14) Menke K H, Steingass H, 1988. Estimation of the energetic feed value obtained from chemical analysis and in vitro gas production using rumen fluid. Animal Research and Development. 28: 7- 55.

15) Moncoulon R, Auclair E, 2001. Utilisation du BIOSAF® Sc 47 pour la production de viande de taurillon. Rapport de Recherche. pp17.

16) Norton B W, 1994. Tree Legumes as dietary supplements for ruminants. In Gutteridge RC and Shelton HM: Forage tree legumes in tropical agriculture. CAB International, 192-201.

17) Rey Mickael, 2012. Implantation du microbiote et mise en place des fonctions du rumen chez le veau de race laitière et effet de la supplémentation en levures vivantes. Thèse doctorat. Université de Toulouse (Institut National Polytechnique de Toulouse (INP Toulouse)). Sciences écologiques, Vétérinaires, Agronomiques et Bioingénieries (SEVAB)). UMR 1289 INRA-INP/ENVT 'TANDEM'. 323 pages.

18) Orskov E R, Macdonald I, 1979. The estimations of protein degradability in the rumen from incubation measurements weighted according to rate passage. Journal of Agriculture Science Cambridge, 92, 499502 .

19) SAS Statistical Analysis System, SAS. 2000. In User's Guide (8Ed). Cary, North Carolina, USA: SAS Institute Inc.

20) Sauvant D, 1981. Alimentation des ruminants, Ed. INRA, France. Prévision de la valeur énergétique des aliments concentrés et composés pour les ruminants. In «Prévision de la valeur nutritive des aliments des ruminants (Eel. C. nimarquilly.), ZlS7-258, INRA Publications. Roule de Saiut-Cvr, 78000 Versailles, (France). $580 \mathrm{p}$.

21) Sauvant D, Giger-Reverdin S, 2016. Approche quantitative de l'acidose chez les ruminants. Bulletin de l'Académie Vétérinaire de France, 2015, 168 (3), pp.260-266. 